\title{
A Comparative Study of Understanding of Menstrual Process among Married Women Belonging to Two Ecological Settings
}

\author{
Rajni Dhingra*, Sarika Manhas, Nidhi Kohli and Asiya Mushtaq \\ P.G. Department of Home-Science, University of Jammu, Jammu 180 006, \\ Jammu and Kashmir, India \\ Telephone: 0191-2454137, *Cell: 09419104644, Fax: 0191-2457137 \\ *E-mail: rajni.dhingra@rediffmail.com
}

KEYWORDS Menstruation. Menarche. Physiological process. Personal Hygiene

\begin{abstract}
Menstruation is a process of utmost importance in the reproductive physiology of females. The present study aims at assessing the understanding of menstruation process among married women and to gain insight into the sources of information and nature of knowledge pertaining to the physiological process under consideration. The sample for the study comprised of 200 married women in the age group of 20-40 years. Equal numbers of women were drawn from two ecological settings (Rural and Urban) of Jammu District, through stratified random sampling technique. The tools for data collection included interview schedules. The results reflected a picture of ignorance and lack of understanding among respondents regarding the physiology and importance of menstrual process particularly among rural respondent $\left(\chi^{2}=35.24\right.$, *Significant at $\left.1 \%\right)$. Their explanation of menstruation reflected incomplete knowledge, unscientific notions and blindfold faith in cultural taboos, myths and social customs pertaining to practices and procedures. Besides these, rural respondents also associated a variety of negative physical and psychological changes with menstruation. Marked differences were also evident in the perception of urban and rural respondents regarding the right age of menarche $\left(\chi^{2}=64.72\right.$, *Significant at $\left.1 \%\right)$, prior information regarding menstruation $\left(\chi^{2}=13.20, *\right.$ Significant at $\left.1 \%\right)$ and cleanliness measures adopted. Among the varied sources of information, mass media especially television and magazines, were found to be the major source of information among urban respondents, which is credited for their awareness regarding menstrual health and hygiene particularly in the usage of napkins, bathing and personal care. Elder female members of the family especially mothers and sisters were the major accessible source for rural respondents, who themselves lacked accurate and adequate knowledge, and hence continued the age-old customs and traditions, some of them lacking scientific vigor.
\end{abstract}

\section{INTRODUCTION}

Menstruation is a physiological process, which is associated with the ability to marry and reproduce (Garg, 2001). The name 'menstruation' comes from the Latin 'menses' meaning month and Greek word 'mene' meaning moon, with reference to the fact that lunar month is also approximately 28 days long and a complete menstrual cycle usually takes about 28 days (Chandra and Alexander, 1999). However, it may take anything from 20 days to 35 days depending upon the personal body rhythm. The first appearance of the menstrual flow in the girls indicate the mature stage of uterine development, though it does not signify the attainment of full reproductive function (Tanner et al., 1977).

The age at menarche is widely considered as an important landmark in sexual maturity (Sidhu and Grewal, 1980). However, it varies widely, even within the same population and is influenced by many factors like climate, geographical, socioeconomic conditions and many other factors of genetic and non-genetic nature (Mehta et al., 1991).
While most girls start menstruating between the ages of 11-14 years, some may begin as early as 9 years and others not until they are 16 years or so, with a mean age of 13.5 years in India (Chakravarti and Renuka, 1971; Gupta, 1990; Singh et al., 1999). Starting at such a tender age, menstruation is never looked upon as a normal or natural process, instead as an unfavourable and embarrassing occasion, which should be hideous and strictly dealt with, thus creating a life-long negative attitude (Garg, 2001). There are infact many misconceptions, superstitions, taboos and myths associated with menstruation that have not been at all flattering to womankind. The vernacular referring of menstruation as 'a curse' (Chandra and Alexander, 1999) suggests of menstruation as a period of physical and mental discomfort, a sense of unworthiness. Many of the taboos and negative association stem directly from the fear of men and male dominated religious and socio-cultural customs. These misconceptions are not only related to the process, but also health and hygiene practices during these periods like avoidance of bathing, changing of clothes and usage of 
unhygienic materials for soaking of menstrual blood and many others (www.Nihfw.org/asp/\#1) which paves way to many reproductive tract infections (Wasserheit and Chakarborty, 1989). The major cause behind such misconceptions is the lack of education, awareness and personal and social inhibitions in discussing such matters especially in rural areas. In keeping with the important role of menstruation in reproductive health of women and young girls, the present study was conducted to get an insight into understanding of menstrual process, its importance and concepts of health and hygiene among married women belonging to two different ecological setting (Rural and Urban) of Jammu. The purpose of the study was to assess the differences in awareness levels of both the groups and accordingly determine the areas where intervention is needed.

\section{METHODOLOGY}

The sample for the present study comprised of 200 married females, 100 each selected form urban and rural setting. The selected females were in the group 20-40 years. The urban sample was selected from 23 wards of Jammu (Jammu and Kashmir), which were clubbed into 4 groups on account of their proximity. For rural group, sample was selected from 12 blocks of Jammu district, which was again clubbed into 4 heads. 25 women from each group were selected at random (lottery method) and included in the study.

The tools for data collection included semistructured interview schedules. An interview schedule was formulated to cover areas such as understanding of menstrual process, importance of menstruation, normal age for menstruation, average age at menarche and sources of information.

Content analysis of the results obtained was carried out. Percentages were calculated to draw out differences in the responses and to highlight major responses. Chi-square test was also applied to study the significant differences in the responses obtained from the two groups of respondents.

\section{RESULTS AND DISCUSSION}

Demographic Profile: The sample group was equally divided among two age groups (20-30 years and 31-40 years) both among rural and urban ecological settings. All the respondents in the urban area were literate where as in rural area $33 \%$ were illiterate. A large number of female respondents $(29 \%)$ had only passed fourth standard where as just one was graduate in rural area. In urban area $34 \%$ of females were high school passed and $22 \%$ were graduates. So, there was a difference in educational level of respondents across the two settings. Occupation plays an important role in our life. It provides us with livelihood and also shows our social status. In this study most of the females i.e. $76 \%$ in urban area and $71 \%$ in rural area were not employed. $27 \%$ of women in rural area and $15 \%$ in urban area were self employed and very small percentage i.e. $2 \%$ in rural and 9\% in urban area were in government.

Menstruation Process: In response to the questions related to conceptual understanding of the process of menstruation, a large majority of respondents in both ecological settings could not demonstrate a scientifically logical understanding of the process (Table 1). In a typical sequence of words which indicated their looking upon the process as something natural they

Table 1: Menstruation process

\begin{tabular}{lrrr}
\hline Type of setting & $\begin{array}{c}\text { Urban } \\
n \%\end{array}$ & $\begin{array}{c}\text { Rural } \\
n \%\end{array}$ & $\begin{array}{c}\text { Total } \\
n \%\end{array}$ \\
\hline Category & & & \\
Just happens & 29 & 34 & $63(31.5 \%)$ \\
Curse on women & 9 & 26 & $35(17.5 \%)$ \\
Internal bleeding & 33 & 28 & $61(30.5 \%)$ \\
Cyclic process & 29 & 12 & $41(20.5 \%)$ \\
\hline Total & 100 & 100 & $200(100.0 \%)$ \\
\hline
\end{tabular}

responded that 'it just happens'. 61 respondents thought that it was a result of internal bleeding but could not identify the organs involved (i.e. reproductive organs). A comparatively larger majority of women in rural area $(26 \%)$ revealed a definitely negative attitude towards menstruation while more urban women (29\%) understood it as a cyclic process, thus depicting semi-scientific reasoning.

Importance of Menstruation: While assessing the awareness of the respondents regarding the importance of menstruation, it was found that in both urban (94\%) as well as rural (84\%) areas, majority of women related menstruation only to reproduction (Table 2). Very few respondents realized its importance for physical development. Also, there were some women who held unscientific notions and could not explain the 
Table 2: Importance of menstruation

\begin{tabular}{lccc}
\hline Type of setting & $\begin{array}{c}\text { Urban } \\
n \%\end{array}$ & $\begin{array}{c}\text { Rural } \\
n \%\end{array}$ & $\begin{array}{l}\text { Total } \\
n \%\end{array}$ \\
\hline $\begin{array}{l}\text { Importance } \\
\text { Not necessary, }\end{array}$ & 3 & 14 & $17(8.5 \%)$ \\
$\quad \begin{array}{l}\text { Just Happens } \\
\text { For physical } \\
\text { development }\end{array}$ & 1 & 1 & $2(1 \%)$ \\
$\begin{array}{l}\text { For reproduction } \\
\text { For physical } \\
\text { development and } \\
\text { reproduction }\end{array}$ & 94 & 84 & $178(89 \%)$ \\
\hline Total & 2 & 1 & $3(1.5 \%)$ \\
\hline
\end{tabular}

occurrence or importance of this process. The computation of chi-square $\left(\chi^{2}=35.24\right.$, Significant at $1 \%$ ) further supported the results.

Normal Age for Menstruation: Majority of urban females $(71 \%)$ reported that average age for commencement of menstruation is 12-13 years where as majority of rural females $(70 \%)$ considered it to be 14 years (Fig. 1). Even though very small percentage of the respondents $(11 \%)$ reported that the age of menstruation had gone down to 10-11 years. It was observed that most of them felt that in the coming times menstruation at tender ages would become an everyday phenomenon. The respondents opined that the right age for menarche was any age at which the process started.

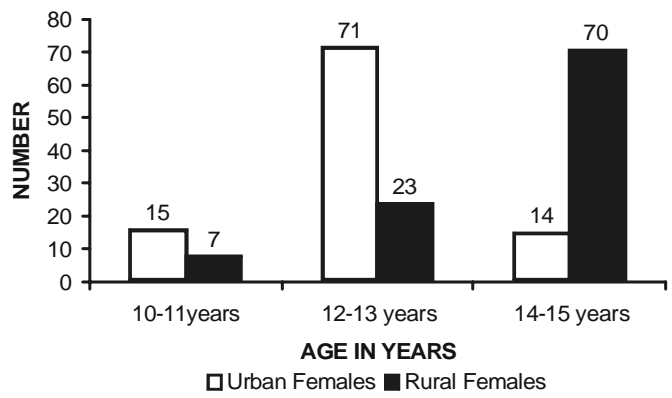

Fig. 1. Normal age for mensuration

Prior Information Regarding Menstruation: The respondents were required to share whether they had any prior information regarding menstruation. The results revealed that there was a significant difference between urban and rural females regarding this aspect $\left(\chi^{2}=14.20\right.$ Significant at $1 \%$ ). Majority of urban females $(45 \%)$ had partial information while majority of rural females $(55 \%)$ had no prior information regarding menstruation. Less than a quarter of urban $(23 \%)$ women had complete information regarding this process (Table 3 ). In face of the first experience of menstrual cycle those women who had no prior information at all were horrified or scared, while those who had at least some information were relaxed and were not awestruck.

Table 3: Prior information regarding menstruation

\begin{tabular}{lcrc}
\hline Type of setting & $\begin{array}{c}\text { Urban } \\
n \%\end{array}$ & $\begin{array}{c}\text { Rural } \\
n \%\end{array}$ & $\begin{array}{l}\text { Total } \\
n \%\end{array}$ \\
\hline Prior information & & & \\
No & 32 & 55 & $87(43.5 \%)$ \\
Partial & 45 & 23 & $68(34 \%)$ \\
Yes & 23 & 22 & $45(22.5 \%)$ \\
\hline Total & 100 & 100 & $200(100.0 \%)$ \\
\hline
\end{tabular}

$\chi^{2}=14.20 *, *$ Significant at $1 \%$

Sources of Information: There were varied sources of information from which the sample women derived information about the process. For urban females, media sources such as T.V. (24\%) and Magazines proved to be valuable sources. Apart from mass-media, elder members of family especially mothers $(28 \%)$ and sister $(15 \%)$ were the important sources of information (Table 4). These women reported that it was always better to inquire from elder women because they could provide realistic and first hand information. Further, sources like relatives, friends and schools were also important in few other cases.

Table 4: Sources of information

\begin{tabular}{|c|c|c|c|}
\hline Type of setting & $\begin{array}{c}\text { Urban } \\
n \%\end{array}$ & $\begin{array}{c}\text { Rural } \\
n \%\end{array}$ & $\begin{array}{r}\text { Total } \\
n \%\end{array}$ \\
\hline \multicolumn{4}{|l|}{ Sources of Information } \\
\hline Media & & & \\
\hline Television & 24 & 6 & $30 \% 15 \%)$ \\
\hline Radio & - & 1 & $1(0.5 \%)$ \\
\hline Magazine & 11 & 5 & $16(8 \%)$ \\
\hline \multicolumn{4}{|l|}{ Family Members } \\
\hline Mother & 28 & 6 & $34(17 \%)$ \\
\hline Sister & 15 & 21 & $36(18 \%)$ \\
\hline \multicolumn{4}{|l|}{ Relative } \\
\hline Cousin & 2 & 1 & $3(1.5 \%)$ \\
\hline Chachi (Aunt) & 7 & 9 & $16(8 \%)$ \\
\hline Massi (Mother's Sister) & 5 & 7 & $12(6 \%)$ \\
\hline \multicolumn{4}{|l|}{ Friends } \\
\hline Neighbourhood & 1 & 12 & $13(6.4 \%)$ \\
\hline Classmates & 6 & 1 & $7(3.5 \%)$ \\
\hline \multicolumn{4}{|l|}{ School } \\
\hline Male Teacher & - & - & - \\
\hline Female Teacher & 8 & 1 & $9(4.5 \%)$ \\
\hline None & 1 & 32 & $33(16.5 \%)$ \\
\hline Total & 100 & 1002 & $200(100.0 \%)$ \\
\hline
\end{tabular}


On the other hand, for rural females, sisters $(21 \%)$ and friends (12\%) were the commonly referred sources. At the same time a striking $32 \%$ of these rural women reported that they never inquired about this process from everyone. Thus a sharp difference was noted among the respondents regarding the openness to inquire about the process.

Maintenance of Cleanliness: Most of the urban females $(74 \%)$ used readymade napkins during monthly menstrual cycle while most of rural females (87\%) used homemade napkins (Table 5). These homemade napkins were usually made up of old torn out clothes. The main reasons for using these were the inability to buy costly readymade sanitary napkins or lack of availability in rural areas. However, Wasserheit and Chakraborty (1989) in their study revealed that women who use rags prepared at home to absorb menstrual blood were twice as likely to have bacterial vaginosis as women using nothing during menstruation. Further, more urban (72\%) than rural women (58\%) bathed and washed regularly during their periods. On the whole, urban females were found to be more hygiene conscious than their rural counterparts.

Table 5: Maintenance of cleanliness

\begin{tabular}{|c|c|c|c|}
\hline Type of setting & $\begin{array}{r}\text { Urban } \\
n \%\end{array}$ & $\begin{array}{r}\text { Rural } \\
n \%\end{array}$ & $\begin{array}{r}\text { Total } \\
n \%\end{array}$ \\
\hline \multicolumn{4}{|l|}{ Category } \\
\hline \multicolumn{4}{|l|}{ Kind of napkins } \\
\hline Home Made & 6 & 8 & $93(46.5 \%)$ \\
\hline Readymade & 94 & 13 & $107(53.5 \%)$ \\
\hline \multicolumn{4}{|l|}{ Bathing and Washing } \\
\hline Once & 72 & 58 & $130(65 \%)$ \\
\hline $2-3$ times & 12 & 23 & $35(17.5 \%)$ \\
\hline Depends on situation & 8 & 19 & $27(13.5 \%)$ \\
\hline Deodorant & 22 & 2 & $24(12 \%)$ \\
\hline Total & 100 & 100 & 200 \\
\hline
\end{tabular}

\section{CONCLUSIONAND IMPLICATIONS}

The present study was carried out with an aim to assess the perception of females towards menstruation and to gain insight into the sources of information and nature of knowledge pertaining to the physiological process under consideration. The results revealed that on the whole majority of respondents from both the settings were unaware of actual physiology of the menstrual process. Their explanation of menstruation reflected incomplete knowledge and more typically a variety of misconceptions or ignorance. In attempting to explain menstruation they ended up focusing on one particular element of the process that is blood/uterus. When inquired about the importance of menstrual process, majority of respondents in both the settings related it with reproduction without having proper knowledge of location and function of reproductive structure and actual physiology of menstrual process. Similar results of ignorance and misconception of menstrual process was also reported by Koffe and Rierdan (1995) among adolescent girls.

The picture of ignorance and wrong understanding of menstrual process was even worse among rural masses. The rural respondents besides being ignorant also associated a variety of unscientific (physical and psychological) changes with menstruation. They considered it as a 'curse upon them', which prevents them from performing any religious duties and rituals. On the other hand, though urban respondents were comparatively more aware of the physiological facts and importance of menstrual process, yet they also continued to adopt the cultural stereotypes and taboos associated with menstruation. These results are supported by the findings of Garg (2001) who reported prevalence of cultural taboos like avoidance of religious practices and sex by women during menstrual periods. Jaswal and Jaswal (1981) also observed that women were restricted to go near the sleeping places of their husbands during their menstrual period.

A difference of about 2-3 years was observed in the opinion of respondents regarding the 'normal age of menarche' in the ecological settings studied. In urban settings the normal age of menstruation was found to be 12-13years, while the rural respondents perceived the normal menstrual age to be 13-14 years. This was probably due to the fact that rural respondents had their first menstrual period later as compared to urban respondents. Charkravarti and Renuka (1971) also reported that mean age of menarche of rural girls was later than urban girls. However, in both the settings, a decline in menstrual age was reported which was related to changing dietary habits and exposure to sexual information Cui Meiujing et al. (1981) also remarked that age at menarche was closely related to nutritional effects especially proteins in diet and changing social conditions. Among the varied sources of information regarding menstruation, massmedia especially television and magazines were 
the most popular among urban respondents. Likewise Devi et al. (1990) also stressed on the important role of media sources. Bhende (1993) also reported that exposure to mass-media enlightens the general public about their body system and strengthens their motivation. Apart from mass-media, elder members of family especially mothers and sisters were also important informative sources, particularly in rural settings. This result is in accordance with the findings of Koffe and Rierdan, (1995) who found that girls usually consult their mothers regarding reproductive and menstrual problems. In both the settings fathers were completely excluded as a source of information( Koffe and Rierdan, 1995). It was also observed that girls felt uncomfortable while talking to their fathers regarding menstrual or other reproductive matters.

As far as menstrual health and hygiene is considered, urban respondents were far more conscious than their rural counterparts. Regular bathing, changing of clothes during periods and use of sanitary napkins was highly prevalent among urban respondents, while in rural areas old and torn out cloth was still the commonly used material during menstruation. Similar use of home made pads made of unwashed clothes for absorbing menstrual blood was reported by Baridalyne and Reirdan (www.nihfw.org/asp/\#1) which gives rise to many infections for example bacterial vaginosis (Wasserheit and Chakarborty, 1989).

Since these results presented a picture of ignorance, unawareness and misunderstanding of menstrual process among respondents belonging to both the settings under consideration, particularly in rural areas, which had paved way for misinformation and following of many myths, taboos and false symptoms relating to physiology and practice of said process. To over come such misconceptions and to promote healthy reproductive life among couples certain steps need to be taken at both community and personal levels. There is a need of introducing reproductive health awareness as one of the dimensions of future sexual and reproductive health programmes in which not only the females but males should also be sensitized about reproductive health and hygiene. However, before bringing any change in menstrual practices, general awareness should be created among masses especially women regarding their own body, secondary sex characteristics and physiology of menstrual process along with development of positive attitude towards pubertal changes. Further, there is a need of providing emotional support and assurance that menstruation is a normal and healthy phenomenon and not a curse, an embracing or frighten-ing process.

All this can be achieved by effective use of mass-media (TV, Radio, magazines) for conducting educative programmes about reproductive health, menstruation, selection of sanitary absorbent material and its proper disposal. Moreover, schools can also play an important role in disseminating knowledge by incorporating sex education in curriculum. Apart from these, in rural areas, nongovernmental organizations, public health centers, panchayati bodies and local leaders can be an effective means for reaching rural areas

In short there is a need of conceptualization of menstrual education as a long-term continuous process, which should begin well before menarche and continue long after.

\section{REFERENCES}

Baridalyne. N and Reirdan V.: Menstrual knowledge, beliefs and practices of women in reproductive age group residing in an urban resettlement colony of Delhi.www.nihfw.org.asp/\#1 (1999).

Bhende, A.A.: A study of sexuality of adolescent girls and boys in urban privileged groups in Mumbai. Paper presented at workshop on sexual aspects of AIDS/ STD prevention in India, November 23-27, 1993. TISS, Mumbai (1993).

Chakravarti R. and Renuka S.: The trends of age at menarche in India. Journal of Social Research (13): 346-348(1971).

Chandra and Alexander.: Reproductive health issues of women. www.nihfw.org. (1999).

Cui. Meiujing, Xujiujin, Chen Liangzhond Wang Yongja Maozhongrang, Li Shaowu, Duan Zhangring and Du Dheju. Genetic Acadimic Sinica, 32: 53-54 (1981).

Devi, A., Sharma, M. and Kumar, S.: Sexuality among Indian Women. Discovery Publishers, Delhi (1990).

Garg, S., Sharma N. and Sahay R.: Socio-cultural aspects of menstruation in an urban slum in Delhi India. Reproductive Health Matters, May a(n): 16-25 (2001).

Gupta, A.: Age at Menarche and Menopause among Three Caste Groups of Jammu. Unpublished M.Sc. Dissertation, P.G. Department of Home Science, University of Jammu, pp. 21-40 (1990).

Jaswal, I.J.S. and Jaswal, S.: Age at menarche among the Apatani of Arunachal Pradesh. Bulletin of Department of Anthropology. Dibrugarh University, 10: 5-60 (1981).

Koffe and Rierdan: www.maabatahali.org/ments/html (1995).

Mehta, S., Qamar, B. R. and Deodhar, S.D.: A mixed 
longitudinal study on the pattern of pubertal growth, relationship to socio-economic status and caloric intake. Indian Journal of Pediatrics, 28(2):147-56 (1991).

Sidhu, L.S. and Grewal, R.: Age of menarche in various categories of Indian Sports women. British Journal of Sports Medicine, 14(4): 199-203(1980).

Singh, M.M., Devu. R., and Gupta, S.: Awareness and health seeking behaviour of rural adolescent school girls on menstruation and reproduction health problems. Indian Journal of Medicinal Sciences, 53(10): 439- 441(1999).

Tanner J.M., Harrison, G.A., Weiner, J.S. and Barricot N.A.: Human Growth and Construction. Oxford Univ. Press, London, Pp. 301-385 (1997).

Wasserheit Indith J.R., Chakraborty. :Reproductive Tract infections in family planning in Rural Bangladesh A neglected opportunity to promote MCM-F Prog. Studies in Family Planning, 26: 69-70 (1989). 